\title{
A comparative study of information content of cash flow, cash value added, accounting earnings, and market value added to book value of total assets in evaluating the firm performance
}

\author{
Mohammad Delkhosh ${ }^{1 *}$, Zahra Malek $^{2}$, Maryam Rahimi ${ }^{3}$, Zohrehfarokhi $^{4}$ \\ ${ }^{1}$ Department of Accounting, Islamic Azad University, Bardaskan Branch, Bardaskan, Iran, Email:mdelkhosh54@iaubc.ac.ir \\ ${ }^{2}$ Department of Accounting, Islamic Azad University, Bardaskan Branch, Bardaskan, Iran \\ ${ }^{3}$ Ph.D. student of Accounting, Department of Accounting, Islamic Azad University, Bandar Abbas Branch, Bandar Abbas, Iran. \\ ${ }^{4}$ Department of Accounting, Islamic Azad University, Bardaskan Branch, Bardaskan, Iran \\ *Corresponding author E-mail: zohreh.farokhi@ rocketmail.com
}

\begin{abstract}
The aim of the present study was to compare the utility of traditional accounting reporting and financial reporting for performance evaluations. Accordingly, the relationship between six ratios of net cash flows, net operating cash flows, cash value added, income after tax, income before tax, and market value added to the book value of total assets and Tobin's Q ratio as an indicator of performance evaluation were examined. For this purpose, the information of 122 companies listed on Tehran Stock Exchange in the years 2009 to 2014 were used. Besides, linear regression and analysis of variance (ANOVA) were used to analyze the data. The results showed that except for the ratio of net cash flows to the book value of total assets, there was a significant relationship between the other five ratios. In addition, it was noted that cash value added to net operating cash flows had more information content concerning evaluating the firm performance. The results also indicated that net cash flows did not contain information content for evaluating the firm performance. However, the market value added had the maximum information to be used for evaluating the firm performance.
\end{abstract}

Keywords: Cash Value Added; Market Value Added; Net Cash Flows; Net Operating Cash Flows; Valued Added; Tobin's Q Ratio.

\section{Introduction}

Shareholders and investors are very interested in the performance of a firm in which they are making investments as are seeking to increase their wealth, so they tend to invest in a firm where their wealth increases. Shareholders and investors are willing to evaluate the performance of management, so they use multiple sources of information and various reports. One of the key information in the financial statements is accounting for profit. However, the potential conflict of interest among managers, shareholders, and other users of financial statements casts some doubts on the benefits of using profits. This is why many financial analysts tend to use cash flows. Issues such as profit before tax and profit after tax are related to the field of profit and income. Cash's value added and market value added are also among other sources of information and reports used by shareholders and investors. Obviously, such information and reports can provide different types of information.

\section{Statement of the problem}

Shareholders, investors, and creditors provide the management with operational and financial resources. These resources are classified into different classes of assets that are used by the management in economic activities. In order to fulfill their accountability concerning how to use these resources and to fulfill the legal requirements of economic activities using accounting as an information system, the management reports basic financial statements and notes to the financial statements for internal and external users of such reports. There are some reports in accounting that are oriented to cash accounting information such as cash flows. There are also some reports, which deal with accrual accounting such as earnings. On the other hand, some scales have been developed in the field of economics with cash orientations for accounting such as cash value added and scales with accrual orientation with information content. Many financial analysts use accounting profit in equity valuation models and in evaluating the performance of the enterprises. However, it is worth mentioning that estimates and predictions are used to measure accounting profit. Besides, there are several accounting approaches (e.g. different methods of measuring depreciation) which can affect the profit rate. Now the question that comes to mind is: What is the role of accounting earnings on an accrual and cash flow basis in evaluating the performance of enterprises?

The question that how is the quality of the information content of such reports and scales for improving the management performance is a problem that can be explored. On the other hand, we know that the suppliers of the company's resources evaluate the management performance using different approaches and scales. One of these scales is Tobin's Q ratio. An investigation 
of the relationship between this ratio and reports by the accounting information system can somehow show the information content of various reports such as earnings, cash flows, cash value added, and market value added.

\section{Summary of studies conducted in Iran and abroad}

Table 1 summarizes studies conducted in Iran as follows:

Table 1: Studies Conducted in Iran

\begin{tabular}{|c|c|c|c|}
\hline Title & Researcher(s) & Year & Results \\
\hline $\begin{array}{l}\text { Application of Tobin's Q ratio } \\
\text { and comparing it with other } \\
\text { management performance } \\
\text { evaluation criteria }\end{array}$ & RaminZara'ati & 2007 & $\begin{array}{l}\text { 1. the use of Tobin's Q ratio in } \\
\text { listed companies in Tehran Stock } \\
\text { Exchange still has no place. } \\
\text { 2- Tobin's Q ratio is significant- } \\
\text { ly related to stock prices, return } \\
\text { on assets, and dividends per } \\
\text { share but it has no significant } \\
\text { relationship with current ra- } \\
\text { tio,quick ratio, asset turnover, } \\
\text { residual income, sales growth, } \\
\text { operational earnings, and sales. }\end{array}$ \\
\hline $\begin{array}{l}\text { the relationship between } \\
\text { changes in market value added, } \\
\text { economic valued added, and } \\
\text { Tobin's Q ratio }\end{array}$ & MojtabaKarimi & 2006 & $\begin{array}{l}\text { Economic valued added } \\
\text { andTobin's Q ratio has the ex- } \\
\text { planatory power concerning } \\
\text { changes in market value added. } \\
\text { However, the market value add- } \\
\text { ed do not have the explanatory } \\
\text { power concerning economic } \\
\text { valued added. }\end{array}$ \\
\hline $\begin{array}{l}\text { The application of Tobin's Q } \\
\text { ratio and its comparison with } \\
\mathrm{P} / \mathrm{E} \text { and } \mathrm{P} / \mathrm{B} \text { ratios in predict- } \\
\text { ingthe return on equity }\end{array}$ & Fahimehpoor Hassan & 2008 & $\begin{array}{l}\text { Tobin's Q ratio has stronger } \\
\text { predictive power than } \mathrm{P} / \mathrm{E} \text { and } \\
\mathrm{P} / \mathrm{B} \text { ratios in predicting equity } \\
\text { returns. }\end{array}$ \\
\hline $\begin{array}{l}\text { Strategic Financial Manage- } \\
\text { ment Review on the Financial } \\
\text { Success of an Organization }\end{array}$ & Ali RastgarMoghadam\&Etemadi & 2016 & $\begin{array}{l}\text { CVA and EVA have a signifi- } \\
\text { cant relationship with stock } \\
\text { returns. Besides, the correlation } \\
\text { between cash value added and } \\
\text { stock returns is stronger than } \\
\text { thecorrelation between economic } \\
\text { valued added and stock returns. } \\
\text { The financial criterion in create } \\
\text { the stable competitive advantage } \\
\text { that increases the corporate value } \\
\text { and reaches the main aim of the } \\
\text { entire benefactors. }\end{array}$ \\
\hline
\end{tabular}

Table 2: Studies Conducted Abroad

\begin{tabular}{|c|c|c|c|}
\hline Title & Researcher(s) & Year & Results \\
\hline $\begin{array}{l}\text { Corporate governance and firm } \\
\text { performance }\end{array}$ & Kanellos\&Karathanassis & 2007 & $\begin{array}{l}\text { The Higher performance of Tobin's Q } \\
\text { ratio was observed in democratic, } \\
\text { semi-democratic, and dictatorship } \\
\text { firms, respectively. }\end{array}$ \\
\hline $\begin{array}{l}\text { Assets invested in salaries and } \\
\text { benefits of executives, manage- } \\
\text { ment performance and capacity }\end{array}$ & Griffith \&Najand & 2006 & $\begin{array}{l}\text { Management performance was meas- } \\
\text { ured by market value added, Tobin's Q } \\
\text { ratio, and three-year returns. The firm } \\
\text { size has no effect onsalaries and bene- } \\
\text { fits of executives. }\end{array}$ \\
\hline $\begin{array}{l}\text { On the accuracy of different } \\
\text { measures of Tobin's Q }\end{array}$ & Erickson \& Whited & 2006 & $\begin{array}{l}\text { Most measures of Tobin's Q are of poor } \\
\text { quality so it is better to use algorithms } \\
\text { with more details. }\end{array}$ \\
\hline $\begin{array}{l}\text { Corporate governance and perfor- } \\
\text { mance options }\end{array}$ & Pham, Suchard, \&Zein & 2004 & $\begin{array}{l}\text { There was no relationship between, } \\
\text { corporate governance, economic valued } \\
\text { added, and Tobin Q ratio. }\end{array}$ \\
\hline
\end{tabular}

\section{Research objectives}

Following the discussions over the separation of ownership from management and the emergence of a huge conflict of interest between owners and managers, the performance evaluation of firms and their managers and leaders became a topic of interest to various groups such as creditors, owners, government, and even managers. The increase in wealth either through dividends or through an increase in the firm price and the value is important for shareholders. Such evaluations are important to managers concerning evaluating their own performance and performance of other sectors, as well as the amount of compensation paid to them as their inalienable rights (Pazhuhian, 2002). These assessments are also important for governments, banks, and financial-credit institu- tions. However, what is of more importance is seen from the perspective of investors because they are not willing to participate in high-risk investments, and even if they do so, they expect higher returns for higher values (Taghavi, 2002).The The aim of the present study is to compare the utility of traditional accounting reporting and financial reporting for performance evaluations. Besides, the relationship between six ratios of net cash flows, net operating cash flows, cash value added, income after tax, income before tax, and market value added to the book value of total assets and Tobin's Q ratio as an indicator of performance evaluation are examined in this study. 


\section{Research hypotheses}

The following hypotheses were developed and tested during this study:

- H1: There is a significant relationship between the ratio of net cash flows to the book value of total assets and Tobin's $\mathrm{Q}$ ratio as an indicator of the firm performance evaluation.

- $\quad \mathrm{H} 2$ : There is a significant relationship between the ratio of net operating cash flows to the book value of total assets and Tobin's $\mathrm{Q}$ ratio as an indicator of the firm performance evaluation.

- H3: There is a significant relationship between the ratio of cash value added to book value of total assets and Tobin's Q ratio as an indicator of the firm performance evaluation.

- H4: There is a significant relationship between the ratio of net profit after tax to the book value of total assets and Tobin's $\mathrm{Q}$ ratio as an indicator of the firm performance evaluation.

- H5: There is a significant relationship between the ratio of net profit before tax to the book value of total assets and Tobin's $\mathrm{Q}$ ratio as an indicator of the firm performance evaluation.

- H6: There is a significant relationship between the ratio of market value added to the book value of total assets and Tobin's $\mathrm{Q}$ ratio as an indicator of the firm performance evaluation.

\section{Research variables}

\subsection{Independent variables}

The independent variables manipulated in this study are as follows:

1) Net cash flows to the book value of total assets.

2) Net operating cash flows to the book value of total assets.

3) Cash's value added to book value of total assets.

4) Net profit after tax to the book value of total assets.

5) Net profit before tax to the book value of total assets.

6) Market value added to the book value of total assets.

\subsection{Dependent variable}

The dependent variable in this study is Tobin's $Q$ ratio, which is equal to the market value of equities plus book value of debts divided by the book value of total assets.

\section{Methodology}

Scientific research is divided into two categories of experimental and descriptive (non-experimental) studies based on the method of data collection. The present study is a descriptive study which employed regression analysis to test the relationship between variables, and the significance level of models estimated. In other words, the relationship between each variable with Tobin's $\mathrm{Q}$ ratio was tested to determine the significance level of the regression models. To this end, the regression models were estimated using SPSS Software. Afterward, the significance level of the regression models was measured using F-value at $95 \%$ significance level. Accordingly, if the F-value estimated from the regression models was greater than the F-value obtained from the critical value, the regression model would be significant. Besides, Durbin-Watson test was used in this study to determine the autocorrelations of variables.

\section{Population and sampling}

The population under study included firms listed on the Tehran Stock Exchange with following conditions:
1) To be included in the sample, firms should not be among investment companies, financial intermediaries, and insurance companies.

2) The firm capital should only include ordinary shares not preferred shares.

3) The fiscal years of the firms should end in March.

4) The shares of firms under study must have been traded from early 2008 to late 2012 in the Tehran Stock Exchange.

The population in this study consisted of all 444 firms listed on the Tehran Stock Exchange, of which a number of 84 firms were included in the final sample by reviewing their financial statements and imposing the above-mentioned constraints.

\section{Testing research hypotheses and results}

The data from the research sample were analyzed using the Pearson correlation test and linear regression test by SPSS and Excel with the following results:

1) The results of the linear regression test for the first hypothesis indicated, that is the significance level is equal to 0.123 , which is greater than $0.05(\mathrm{P}>0.05)$. Therefore, the first hypothesis was not confirmed. Accordingly, there is no significant relationship between the ratio of net cash flows to the book value of total assets and Tobin's Q ratio as an indicator of the firm performance evaluation. (Table 1.2)

2) The results of the linear regression test for the second hypothesis indicated, that is the significance level is equal to 0.000 , which is less than 0.05 ( $\mathrm{P}>0.05)$. Therefore, the second hypothesis was confirmed. Accordingly, there is a significant relationship between the ratio of net operating cash flows to the book value of total assets and Tobin's Q ratio as an indicator of the firm performance evaluation. (Table 2.2)

3) The results of the linear regression test for the third hypothesis suggested, that is the significance level is equal to 0.000 , which is less than $0.05(\mathrm{P}>0.05)$. Therefore, the third hypothesis was confirmed. Accordingly, there is a significant relationship between the ratio of cash value added to book value of total assets and Tobin's $Q$ ratio as an indicator of the firm performance evaluation. (Table 3.2)

4) The results of the linear regression test for the fourth hypothesis suggested that the significance level is equal to 0.000 which is less than $0.05(\mathrm{P}>0.05)$. Therefore, the fourth hypothesis was confirmed. Accordingly, there is a significant relationship between the ratio of net profit after tax to the book value of total assets and Tobin's Q ratio as an indicator of the firm performance evaluation. (Table 4.2)

5) The results of the linear regression test for the fifth hypothesis suggested that the significance level is equal to 0.000 which is less than 0.05 ( $\mathrm{P}>0.05)$. Therefore, the fifth hypothesis was confirmed. Accordingly, there is a significant relationship between the ratio of net profit before tax to the book value of total assets and Tobin's $Q$ ratio as an indicator of the firm performance evaluation. (Table 5.2)

6) The results of the linear regression test for the sixth hypothesis showed that the significance level is equal to 0.000 which is less than $0.05(\mathrm{P}>0.05)$. Therefore, the sixth hypothesis was confirmed. Accordingly, there is a significant relationship between the ratio of market value added to the book value of total assets and Tobin's $Q$ ratio as an indicator of the firm performance evaluation. (Table 6.2).

The results of the multiple regression test concerning the relationship between the dependent and independent variables indicated that the significance level is equal to 0.000 which is less than 0.05 $(\mathrm{P}>0.05$ )

Therefore, as shown in the above tables, the multiple regression modelis significant, so the results of the study are summarized as follows:

The results of the simple linear regression analysis indicated that there was no significant relationship between the ratio of the net 
cash flows to the book value of total assets and Tobin's Q ratio. In contrast, there was a significant relationship between the ratios of net operating cash flows to the book value of total assets, cash value added to book value of total assets, net profit after tax to the book value of total assets, net profit before tax to the book value of total assets, and market value added to the book value of total assets. Besides, the results of the multiple regression models concerning the fit to the regression model compared to the backward regression model suggested that the ratios of cash value added to the book value of assets, profit after tax to the book value of assets, profit before tax to the book value of assets, and market value added to the book value of total assets are significantly related toTobin's Q ratio. In addition, the fitted model is presented as follows:

$$
\mathrm{q}=\mathrm{e}^{\left[\begin{array}{l}
-0.497(\mathrm{PAT} / \mathrm{BV})+0.395 \\
1.029(\mathrm{MVA} / \mathrm{BV})+0.074 \sqrt[5]{(\mathrm{PVA} / \mathrm{BV})}+
\end{array}\right]}
$$

$\mathrm{H} 2$ : There is a significant relationship between the ratio of net operating cash flows to the book value of total assets and Tobin's $Q$ ratio as an indicator of the firm performance evaluation.

H3: There is a significant relationship between the ratio of cash value added to book value of total assets and Tobin's $\mathrm{Q}$ ratio as an indicator of the firm performance evaluation.

H4: There is a significant relationship between the ratio of net profit after tax to the book value of total assets and Tobin's Q ratio as an indicator of the firm performance evaluation.

H5: There is a significant relationship between the ratio of net profit before tax to the book value of total assets and Tobin's Q ratio as an indicator of the firm performance evaluation.

H6: There is a significant relationship between the ratio of market value added to the book value of total assets and Tobin's Q ratio as an indicator of the firm performance evaluation.
Pearson correlation coefficient \&Linear Regression

H0 was confirmed.

Pearson correlation coefficient \& Linear Regression

$\mathrm{H} 0$ was rejected.

Pearson correlation coefficient \& Linear Regression

H0 was rejected.

Pearson correlation coefficient \& Linear Regression

H0 was rejected.

Pearson correlation coefficient \& Linear Regression

H0 was rejected.

Pearson correlation coefficient \& Linear Regression Interpretation of Results

The null hypothesis was confirmed. So there is nosignificant relationship between the ratio of net cash flows to the book value of total assets and Tobin's Q ratio. Accordingly, the ratio of net cash flows to the book value of total assets concerning the firm performance has no information content. In other words, net cash flows do not have information content to evaluate the firm performance. The null hypothesis was rejected. So there is a significant relationship between the ratio of net operating cash flows to the book value of total assets and Tobin's $\mathrm{Q}$ ratio. Accordingly, the ratio of net operating cash flows to the book value of total assets concerning the firm performance has information content. In other words, net operating cash flows provide information to evaluate the firm performance.

The null hypothesis was rejected. So there is a significant relationship between the ratio of cash value added to book value of total assets and Tobin's $Q$ ratio. Accordingly, the ratio of cash value added to book value of total assets concerning the firm performance has information content. In other words, cash value added provides some information to evaluate the firm performance.

The null hypothesis was rejected. So there is a significant relationship between the ratio of net profit after tax to the book value of total assets and Tobin's $Q$ ratio. Accordingly, the ratio of net profit after tax to the book value of total assets concerning the firm performance has information content. In other words, net profit after tax provides some information to evaluate the firm performance.

The null hypothesis was rejected. So there is a significant relationship between the ratio of net profit before tax to the book value of total assets and Tobin's $Q$ ratio. Accordingly, the ratio of net profit before tax to the book value of total assets concerning the firm performance has information content. In other words, net profit before tax provides some information to evaluate the firm performance. The null hypothesis was rejected. So there is a significant relationship between the ratio of market value added to the book value of total assets and Tobin's Q ratio. Accordingly, the ratio of market value added to the book value of total assets concerning the firm performance has information content. In other words, market value added provides some information to evaluate the firm performance. 
Table 1.1: Model Summary ${ }^{\mathrm{b}}$

\begin{tabular}{llllll}
\hline Mode & R & R Square & Adjusted R Square & Std. Error of the Estimate & Durbin-Watson \\
\hline 1 & .078 & .006 & .004 & .429093506171235 & 1.406 \\
\hline
\end{tabular}

Table 1.2: Anova $^{\mathrm{b}}$

\begin{tabular}{lllll}
\hline Model & Sum of Squares & df & Mean Square & F \\
\hline Regression 1 & .440 & 1 & .440 & 2.389 \\
Residual & 72.176 & 392 & .184 & $.123 \mathrm{a}$ \\
Total & 72.615 & 393 & & \\
\hline
\end{tabular}

Table 2.1: Model Summary ${ }^{\mathrm{b}}$

\begin{tabular}{|c|c|c|c|c|c|c|}
\hline Model & $\mathrm{R}$ & R Square & Adjusted R Square & Std. Error of the Estimate & \multicolumn{2}{|c|}{ Durbin-Watson } \\
\hline 1 & $.483^{\mathrm{a}}$ & .233 & .231 & .372866028538350 & \multicolumn{2}{|c|}{1.351} \\
\hline \multicolumn{7}{|c|}{ Table 2.2: Anova $^{\mathrm{b}}$} \\
\hline Model & & Sum of $S$ & df & Mean Square & $\mathrm{F}$ & Sig. \\
\hline Regression & & 16.546 & 1 & 16.546 & 119.011 & $.000 \mathrm{a}$ \\
\hline Residual & & 54.360 & 391 & .139 & & \\
\hline Total & & 70.906 & 392 & & & \\
\hline
\end{tabular}

Table 3.1: Model Summary ${ }^{\mathrm{b}}$

\begin{tabular}{llllll}
\hline Mode & R & R Square & Adjusted R Square & Std. Error of the Estimate & Durbin-Watson \\
\hline 1 & .501 & .251 & .249 & .368200173094295 & 1.323 \\
\hline
\end{tabular}

\begin{tabular}{lllll} 
& \multicolumn{3}{c}{ Table 3.2: Anova $^{\mathrm{b}}$} & F \\
\hline Model & Sum of Squares & df & Mean Square & Sig. \\
\hline Regression & 17.809 & 1 & 17.809 & $.000 \mathrm{a}$ \\
Residual & 53.144 & 392 & .136 & \\
Total & 70.953 & 393 & & \\
\hline
\end{tabular}

a. Predictors (Constants): CVA/BV b. Dependent Variable: In-q.

Table 4.1: Model Summary ${ }^{\mathrm{b}}$

\begin{tabular}{|c|c|c|c|c|c|c|}
\hline Model & $\mathrm{R}$ & R Square & Adjusted R Square & Std. Error of the Estimate & \multicolumn{2}{|c|}{ Durbin-Watson } \\
\hline 1 & .690 & .476 & .474 & .332830398362942 & \multicolumn{2}{|c|}{1.361} \\
\hline \multicolumn{7}{|c|}{ Table 4.2: Anova $^{\mathrm{b}}$} \\
\hline Model & & Sum of & df & Mean Square & $\mathrm{F}$ & Sig. \\
\hline Regression & & 39.716 & 1 & 39.716 & 358.522 & $.000^{\mathrm{a}}$ \\
\hline Residual & & 43.757 & 395 & .111 & & \\
\hline Total & & 83.472 & 396 & & & \\
\hline
\end{tabular}

a. Predictors (Constants): PAT/BV b. Dependent Variable: In-q.

Table 5.1: Model Summary ${ }^{\mathrm{b}}$

\begin{tabular}{llllll}
\hline Mode & R & R Square & Adjusted R Square & Std. Error of the Estimate & Durbin-Watson \\
\hline 1 & $.692^{\mathrm{a}}$ & .478 & .477 & .321985376082549 & 1.401 \\
\hline
\end{tabular}

Table 5.2: Anova $^{\mathrm{b}}$

\begin{tabular}{lllll}
\hline Model & Sum of Squares & df & Mean Square & F \\
\hline Regression & 37.365 & 1 & 37.365 & 360.406 \\
Residual & 40.744 & 393 & .104 & $.000^{\text {a }}$ \\
Total & 78.109 & 394 & & \\
\hline
\end{tabular}

a. Predictors (Constants): PBT/BVb. Dependent Variable: In-q.

Table 6.1: Model Summary ${ }^{\mathrm{b}}$

\begin{tabular}{|c|c|c|c|c|c|c|}
\hline Model & $\mathrm{R}$ & R Square & Adjusted R Square & Std. Error of the Estimate & \multicolumn{2}{|c|}{ Durbin-Watson } \\
\hline 1 & $.989^{\mathrm{a}}$ & .978 & .978 & .045476858544777 & \multicolumn{2}{|c|}{1.873} \\
\hline \multicolumn{7}{|c|}{ Table 6.2: Anova $^{\mathrm{b}}$} \\
\hline Model & & Sum of $\mathrm{S}$ & $\mathrm{df}$ & Mean Square & $\mathrm{F}$ & Sig. \\
\hline Regression & & 31.998 & 1 & 31.998 & $1.547 \mathrm{E} 4$ & $.000 \mathrm{a}$ \\
\hline Residual & & .707 & 342 & .002 & & \\
\hline Total & & 32.705 & 343 & & & \\
\hline
\end{tabular}

a. Predictors (Constants): MVA/BV b. Dependent Variable: In-q.

Table 7.1: Model Summary ${ }^{\mathrm{b}}$

\begin{tabular}{llllll}
\hline Model & R & R Square & Adjusted R Square & Std. Error of the Estimate & Durbin-Watson \\
\hline 1 & $.954^{\mathrm{a}}$ & .909 & .908 & .122094058186196 & 1.824 \\
\hline
\end{tabular}

Table 7.2: Anova $^{\mathrm{b}}$

\begin{tabular}{lllll}
\multicolumn{5}{c}{ Table 7.2: Anova } \\
\hline Model & Sum of Squares & df & Mean Square & F \\
\hline Regression & 56.806 & 6 & 9.468 & 635.112 \\
Residual & 5.665 & 380 & .015 & $.000^{\mathrm{a}}$ \\
Total & 62.470 & 386 & & \\
\hline
\end{tabular}

a. Predictors (Constants): ), CVA/BV-1/5, MVA/BV, CF/BV, PBT/BV-1/3, OCF/BV-1/3, PAT/BV B. Dependent Variable: In-q. 
According to the results from testing the research hypotheses, the adjusted coefficient of determination was used as follows to compare the information content of six ratios presented in the form of independent variables:

$$
\left.\left.\left.\left.\mathrm{R}_{(\mathrm{MVA} / \mathrm{BV})}\right\rangle \mathrm{R}_{(\mathrm{PBT} / \mathrm{BV})}^{2}\right\rangle \mathrm{R}_{(\mathrm{PAT} / \mathrm{BV})}^{2}\right\rangle \mathrm{R}_{(\mathrm{CVA} / \mathrm{BV})}^{2}\right\rangle \mathrm{R}_{(\mathrm{OCF} / \mathrm{BV})}^{2}
$$

Our findings showed that the ratio of market value added to book value of assets with the adjusted $\mathrm{R}^{2}$ of 0.989 had the highest information content followed by net profit before tax, net profit after tax, cash value added, and net operating cash flows to the book value of assets, which occupied the other positions, respectively. As it can be seen, there is little difference between coefficients of determination for profit before tax and profit after tax (0.003). Therefore, it can be said that the tax deducted from earnings has little information content. As the aim of the study was to compare the utility of traditional accounting reporting and financial reporting for performance evaluations, the results indicated that the cash value added to have information content than net operating cash flows in evaluating the firm performance. In addition, the net cash flows have no information content concerning the firm performance evaluation. It was also noted that the market value added has the highest information content in relation to the firm performance evaluation.

\section{Implications}

Based on the findings of the study, the following suggestions are offered:

1) Managers are recommended to follow practices such as increases in salaries paid to employees to create more cash value added to the organization. This can result in improved productivity, thus increased profits, and encouragement of employees to male greater contribution to the improvement of the business entity.

2) Investors are advised to prefer the cash value added over the net cash flows and net operating cash flows when making decisions about the management performance evaluation.

Given the strong correlation between the market value added and Tobin's Q, it is suggested that the growth of the firm market value added be taken into account in predicting the management future performance.

\section{References}

[1] Delkhosh. M, Mousavi.H (2016)" Strategic Financial Management Review on the Financial Success of an Organization" Mediterranean Journal of Social Sciences, Vol 7 No 2 S2, pp: 30 - 34

[2] Erickson T; Whited, T.M. (2006). On the Accuracy of Different Measures of Tobin's Q. Financial Management, 5-33. https://doi.org/10.1111/i.1755-053X.2006.tb00145.X.

[3] Fernandez, P. (2008). Three Residual Income Valuation Methods and Discounted Cash Flow Valuation. Social Science Research Network.

[4] Griffith, J.; Najand, M. (2006). REIT Executive Compensation, Performance, and Management Power: Evidence from Panel Data". Journal of Asset Management, 8, pp. 52-57.

[5] Kanellos, T.;Karathanassis, G. (2007). Corporate Governance and Firm Performance: Results from Greek Firms. MPRA Paper, pp: 1 22

[6] Karimi, M. (2006). Relationship between changes in the market value added (MVA), economic value added (EVA), andTobin's Q ratio in listed companies in Tehran Stock Exchange. M.A Thesis University of ShahidBeheshti

[7] Pazhuhian, J. (2002). Principles of economics (1).Darsnameh Publications.

[8] Pham P. K; Suchard, J. A.; Zein, J. (2004). Corporate Governance and Alternative Performance Measures: Evidence from Australian Firms.
[9] Poor Hasan, F. (2008). Application of Tobin's Q and comparing it with $\mathrm{P} / \mathrm{E}$ and $\mathrm{P} / \mathrm{B}$ ratios in predicting the returns on equity of listed companies in Tehran Stock Exchange. M.A Thesis: Islamic Azad University of Mashhad.

[10] RastgarMoghadamEtemadi, A. (2007). The relationship of CVA and EVA with stock returns of listed companies in Tehran Stock Exchange. M.A Thesis: Islamic Azad University of Mashhad.

[11] Taghavi, M. (2002).Financial management (1). Darsnameh Publications.

[12] Zara'ati, R. (2007). Application Tobin's Q ratio and its comparison with other management performance evaluation criteria in listed companies in Tehran Stock Exchange. M.A Thesis: University of Shiraz. 